\title{
An Approach for the Identification of Particulate Matter in the Clouds of Bogotá Using Satellite Imagery Analysis*
}

\section{Aproximación a la identificación de material particulado en las nubes de Bogotá mediante análisis de imágenes satelitales}

Date received: 25 September 2018 | Date approved: 5 March 2019| Date published: 6 December 2019

\author{
Juan Antonio Aragón Moreno ${ }^{\text {a }}$ \\ Universidad Libre, Colombia \\ ORCID: 0000-0003-2768-9082 \\ LAURA ISABEL ESPINOSA MARTÍNEZ \\ Universidad Libre, Colombia \\ ORCID: 0000-0003-0366-5502 \\ Paula Andrea Castañeda Garzón \\ Universidad Libre, Colombia \\ ORCID: 0000-0003-4903-0684 \\ * Research article \\ ${ }^{\text {a }}$ Corresponding author. E-mail: juan.aragonm@unilibre.edu.co
}

DOI: https://doi.org/10.11144/Javeriana.iyu23-2.aipm

How to cite this article:

J. A. Aragón Moreno, L. I. Espinosa Martínez, and P. A. Castañeda Garzón, "An approach for the identification of particulate matter in the clouds of Bogotá using satellite imagery analysis," Ing. Univ., vol. 23, no. 2, 2019. https://doi.org/10.11144/Javeriana.iyu23-2.aipm 
Abstract

Objective: An analysis of the air quality of Bogotá by identifying clouds during the period from 2013-2017 and verifying patterns of behavior between cloud formation and the concentration of particulate matter is presented. Materials and methods: The study sample includes data provided by the Bogotá Air Quality Monitoring Network (RMCAB), taking into account the concentration of particulate matter, temperature, precipitation, wind direction and wind speed. The data are compared with Landsat 8 satellite images and different combinations of spectral bands through the use of the Geographic Information System (GIS) ArcGis. Results and discussion: A high model correlation is reflected in a percentage greater than $90 \%$, presenting a greater coincidence with a periodicity of two years during the dry period; it is possible to observe that the concentration of pollutants follows the trend of the wind vector lines, and the concentration has a direct correlation with cloud formation, which is influenced by temperature, wind speed and wind direction. Conclusions: This paper provides an alternative for the measurement of particulate matter and contributes to the collection of information on this research topic.

Keywords: ArcGis, air quality, atmospheric reflectance and spectral bands, clouds, Landsat 8, meteorological variables, particulate matter, satellite images

\section{Resumen}

Objetivo: Analizar la calidad aire de Bogotá mediante la identificación de nubes correspondiente al periodo 2013-2017, y comprobar patrones de comportamiento entre formación de nubes y concentración de material particulado. Materiales y métodos: La muestra incluye datos proporcionados por la Red de Monitoreo de Calidad del aire de Bogotá (RMCAB), teniendo en cuenta la concentración de material particulado, temperatura, precipitación, dirección y velocidad del viento. Los datos son comparados con imágenes satelitales Landsat 8 y las diferentes combinaciones de bandas espectrales, mediante el uso del Sistema de Información Geográfica (SIG) ArcGis. Resultados y discusión: Se refleja un alto ajuste del modelo de un porcentaje mayor al $90 \%$, presentando una mayor coincidencia en una periodicidad de dos años, en periodo seco; es posible identificar visualmente, que la concentración de los contaminantes sigue la tendencia de las líneas vectoriales del viento, y encontrando una correlación directa con la formación de nubes, influenciado por tendencias de temperatura, velocidad y dirección del viento. Conclusiones: Este documento sirve como alternativa para la medición de material particulado, y aporta a la recolección de información en este tema de investigación.

Palabras clave: ArcGis, calidad del aire, reflectancia atmosférica y bandas espectrales nubes, Landsat 8, variables meteorológicas material particulado, imágenes satelitales 


\section{Introduction}

Air pollution is one of the most worrisome environmental problems and is one of the critical challenges faced by modern societies and growing cities, since it is considered responsible for significant adverse effects on human health [1]-[4], animals, natural ecosystems and the environment [5]. Likewise, the concentration of particulate matter (PM) not only affects human health but also clouds by preventing the proper formation of precipitation [6]. These authors affirm that this effect would have serious potential implications for the availability of water resources and for the global climate due to the effects on precipitation processes because the droplets that make up clouds must initially form around an existing particle, known as the "cloud condensation core", which depends on the purity of the air. In the same way, when air pollution increases due to agents such as PM and vapor emissions, the condensation core increases, and the affected clouds, which contain approximately the same amount of water as the clean clouds, are distributed over a larger number of drops of small size; the resulting accumulation prevents sufficient growth of these droplets to cause precipitation [7], [6], [8].

In Latin America, countries such as Mexico, Chile and Brazil have increased their share of global air pollution, due to factors such as the emission and concentration of pollutants; the cities with the highest concentrations of pollution exceed the limits established by the guidelines of the WHO $\left(20 \mu \mathrm{g} / \mathrm{m}^{3}\right)$ and EU $\left(40 \mu \mathrm{g} / \mathrm{m}^{3}\right)$. In the case of Mexico, the level is double that of the standard, with a value of $85.9 \mu \mathrm{g} / \mathrm{m}^{3}$ [9], [10]. Similarly, the highest concentrations of air pollution are in cities within developing economies, such as the capital of Colombia, and constantly rising, with an annual median concentration of $60 \mu \mathrm{g} / \mathrm{m}^{3}$ registered in 2005 [11], [12]. Industrial activity in this country is concentrated in the regions with the greatest population in the country, mainly in the cities of Bogotá, Cali and Medellín, where most automobiles operate. This has the consequence that the most densely populated urban areas are the places where the greatest amounts of emissions with immediate local effects are generated, having a substance percentage estimate of carbon monoxide (CO) of $57.6 \%$, methane $\left(\mathrm{CH}_{4}\right)$ 20.9\%, suspended particles $8.3 \%$, oxides of sulfur (Sox) $6.6 \%$, oxides of nitrogen (NOx) $3.5 \%$ and others [13]. Therefore, according to the 2016 report of the World Health Organization [1] on air pollution, the main cities in Latin America such as Mexico City, Buenos Aires, Caracas, Bogotá, Lima and Sao Paulo have PM proportions above the recommended values, and Bogotá has been listed as the city

with the fourth highest level of atmospheric pollution by PM10 (i.e., particles present in the atmosphere, in solid or liquid state, with sizes between $2.5 \mu \mathrm{m}$ and $10 \mu \mathrm{m}$ ) [14].

According to the results of the Air Quality State Report in Colombia [15], it is evident that PM has the highest percentage $(85 \%)$ of data capture recorded by monitoring stations, followed by SOx and NOx with $34 \%$, and PM10 presents critical concentrations that are 
above the established level by Colombian air quality regulations. This finding indicates a maximum limit for annual exposure and daily exposure for PM10 of $150 \mu \mathrm{g} / \mathrm{m}^{3}$ and 70 $\mu \mathrm{g} / \mathrm{m}^{3}$, respectively, for 2006 [16], and $100 \mu \mathrm{g} / \mathrm{m}^{3}$ and $50 \mu \mathrm{g} / \mathrm{m}^{3}$, respectively, for 2010 [17]. A similar finding has been reported by the Institute of Hydrology, Meteorology and Environmental Studies (IDEAM-for its acronym in Spanish) in the years 2011-2015, which shows that although there is a decrease in the concentration of PM10, the annual values are above the permissible limits [18].

Several cities in the country do not have enough equipment for monitoring air pollutants. Programs similar to the current prototype are too expensive and only some cities have air monitoring stations that allow access to this information, and good environmental management to control air pollution. Similar investigations have been performed focusing on the identification or characterization of PM in the city of Chennai, India, where the result indicates that pollution can be mapped using satellite information to provide a larger area of coverage, using the visible band reflectance value of Landsat 7 ETM+ [19]. In Palestine, an analysis using the algorithm to estimate the concentration of PM10 over the Gaza Strip based on the Landsat image, yields a positive trend line for the concentration of PM10, showing an average increase in its concentration during the years 2000-2014 [20]. PM10 concentrations have also been calculated, taking into account environmental indices, in Quito, Ecuador. Within the zones with the greatest change in concentration of PM10, certain areas were found where the presence of this contaminant is known and coincides with other analyses carried out for these areas. The indices, however, have no significance for the algorithm developed [21], and in the Universidad del Valle de Colombia, a model with Landsat satellite images was established for the city of Cali through the study of environmental indicators. It helped to define the environmental quality of the city by zones from the integrated analysis of the indicators. Thereafter, a synthetic index of environmental quality was derived that collects $95 \%$ of the variance and responds positively to the beneficial effects of vegetation and negatively to the adverse effects of the concrete areas [22]. Nevertheless, this type of study is still lacking in a tropical city located in high altitude, such as Bogotá.

Bearing in mind that in Bogotá, since there is a monitoring system for PM and meteorological variables with high coverage [23], which has permitted, through new information, the creation of different prevention and air quality policies, or plans to have better atmospheric conditions [24], [25], it will be possible to determine the viability of using satellite images [26], [27], to determine pollution and air quality. At the same time, it will facilitate studies on the incidence of respiratory diseases generated by the presence of PM [28]. 


\section{Materials and Methods}

\section{Study Area}

The study area is limited to the city of Bogotá in the sectors where there are automatic air quality monitoring stations that measure PM10 (Guaymaral, Usaquén, Suba, Las Ferias, Puente Aranda, Kennedy, Sevillana-Carvajal, Tunal, San Cristóbal, Centro de Alto Rendimiento-CAR, MinAmbiente), and the satellite image area corresponds to the area or grid of resolution (Figure 1).

\section{Figure 1. Study area}

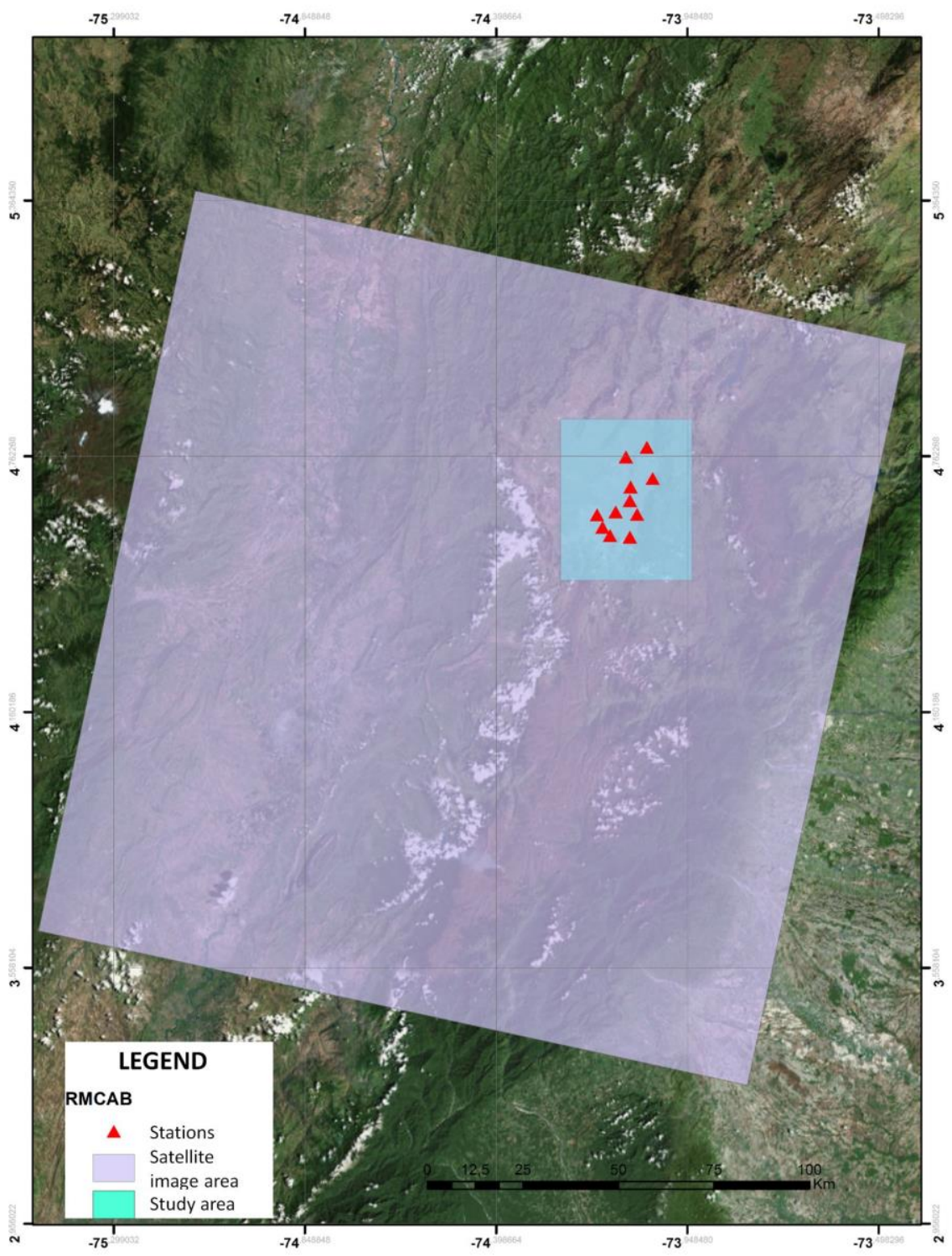

Source: own elaboration 


\section{PMIO and Meteorological Variables}

The meteorological variables that regulate the distribution of PM10 in Bogotá that are considered for the investigation are wind speed (WS), wind direction (WD), precipitation (PP) and temperature (T) to obtain hourly data for the years 2011 to 2017 from RMCAB (its acronym in Spanish) [29] (table 1)

Table 1. RMCAB stations and meteorological variables

\begin{tabular}{cccccc}
\hline \multirow{2}{*}{ Station } & Pollutants & \multicolumn{4}{c}{ Meteorological variables } \\
\cline { 2 - 6 } & PM10 $\left(\boldsymbol{\mu g} / \mathbf{m}^{3}\right)$ & WS $\left({ }^{\circ}\right)$ & WD $(\mathbf{m} / \mathbf{s})$ & $\mathbf{T}\left({ }^{\circ} \mathbf{C}\right)$ & PP $(\mathbf{m m})$ \\
\hline Guaymaral & $\mathrm{x}$ & $\mathrm{x}$ & $\mathrm{x}$ & $\mathrm{x}$ & $\mathrm{x}$ \\
\hline Usaquén & $\mathrm{x}$ & $\mathrm{x}$ & $\mathrm{x}$ & & $\mathrm{x}$ \\
\hline Suba & $\mathrm{x}$ & $\mathrm{x}$ & $\mathrm{x}$ & & $\mathrm{x}$ \\
\hline Las Ferias & $\mathrm{x}$ & $\mathrm{x}$ & $\mathrm{x}$ & $\mathrm{x}$ & $\mathrm{x}$ \\
\hline Puente Aranda & $\mathrm{x}$ & $\mathrm{x}$ & $\mathrm{x}$ & $\mathrm{x}$ & $\mathrm{x}$ \\
\hline Kennedy & $\mathrm{x}$ & $\mathrm{x}$ & $\mathrm{x}$ & $\mathrm{x}$ & $\mathrm{x}$ \\
\hline Sevillana-Carvajal & $\mathrm{x}$ & $\mathrm{x}$ & $\mathrm{x}$ & $\mathrm{x}$ & $\mathrm{x}$ \\
\hline Tunal & $\mathrm{x}$ & $\mathrm{x}$ & $\mathrm{x}$ & $\mathrm{x}$ & $\mathrm{x}$ \\
\hline San Cristóbal & $\mathrm{x}$ & $\mathrm{x}$ & $\mathrm{x}$ & $\mathrm{x}$ & $\mathrm{x}$ \\
\hline CAR & $\mathrm{x}$ & $\mathrm{x}$ & $\mathrm{x}$ & $\mathrm{x}$ & $\mathrm{x}$ \\
\hline MinAmbiente & $\mathrm{x}$ & $\mathrm{x}$ & $\mathrm{x}$ & & $\mathrm{x}$ \\
\hline
\end{tabular}

Source: RMCAB [23]

The missing data were completed utilizing temporal series and ARIMA (Autoregressive Integrated Moving Average) model from the "Gretl" program [30], which offers an interface that gives access to the free software statistical package $\mathrm{R}$ and its bookcase GNU, based on txt and xls files, designed for statistical analysis and model estimation. Once complete information is available, a daily, monthly and annual average can be taken to estimate the behavior and the relationship between variables, spatially and statistically. In the case of the wind speed and direction, the information was taken quarterly, and the WRPLOT was used, a completely operational wind rose program for meteorological data [31].

\section{Landsat 8 and Satellite Images}

The Landsat 8 (table 2) satellite was launched in 2013; thus, for the determination of PM10 concentrations, two annual dates were chosen from the aforementioned year to 2017 from a list of available image dates (September 27, 2013, October 29, 2013, August 29, 2014, October 16, 2014, July 31, 2015, September 17, 2015, July 17, 2016, September 3, 2016, July 4, 2017, October 8, 2017) [32]. Subsequently, three dates were chosen depending on their cloudiness (> $60 \%$ ), humidity period and image coverage. 
Table 2. Distribution of the bands from Landsat 8

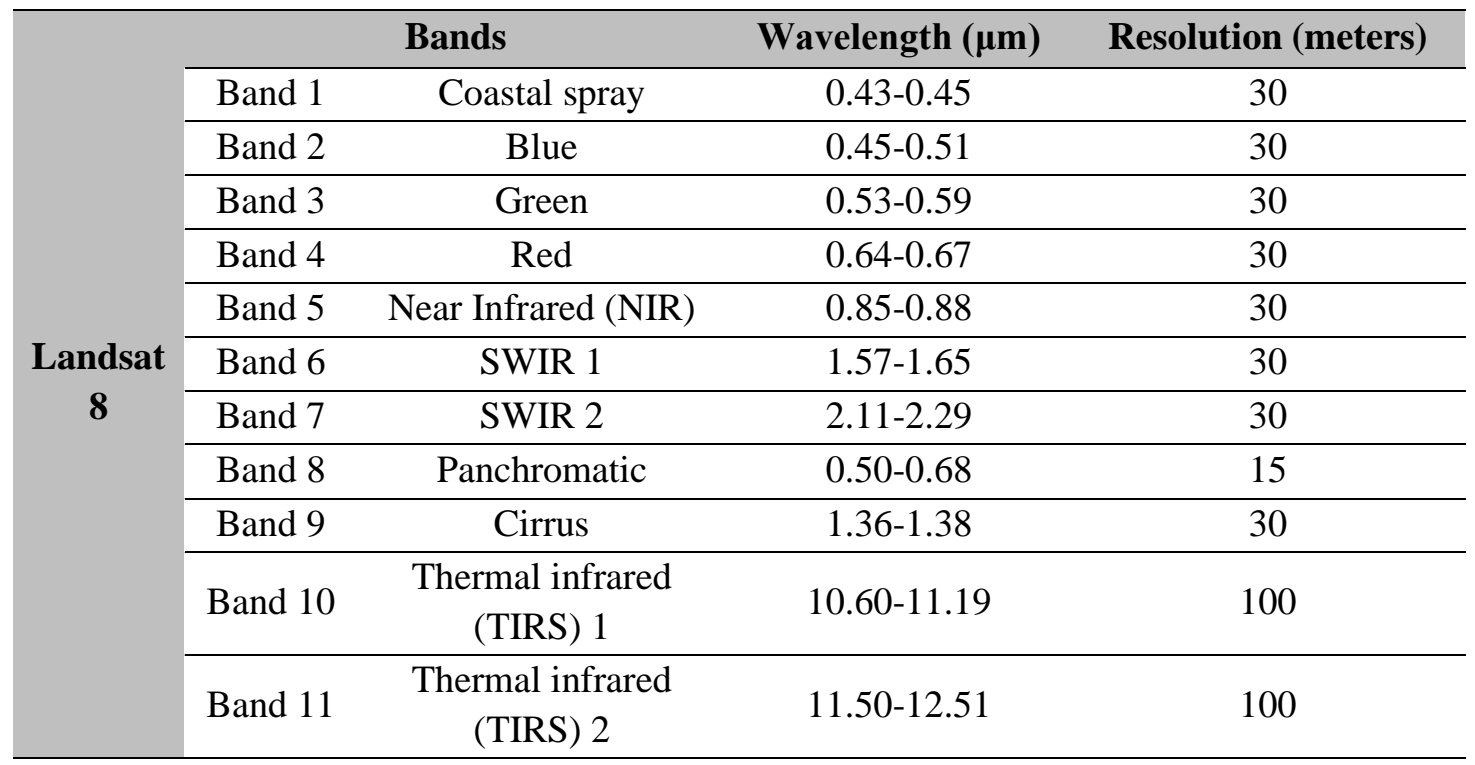

Source: EOS [32]

With the data acquired from the RMCAB, the required interpolation was performed using ArcGis software [33] to obtain isolines of PM10 concentration and behavior for wind speed, wind direction, precipitation and temperature. This allows for the superposition of images and data, comparing trends of cloud formation with PM10 concentration, analysis of its relationship with the meteorological variables of interest, identification of the cloud types that are present in the images of interest, and finding their relation with the pollutant.

\section{Particulate Matter PM10}

Considering the metadata of the images, the procedure established in previous projects was followed, such as the investigations conducted in Chennai, India and Quito, Ecuador [19], [21], by which the sum of daily averages of PM10 of the 11 stations for each date is obtained. The reflectance is obtained by averaging the maximum and minimum per band, and obtaining a linear trend equation, which is used to determine the algorithm coefficient. This is achieved by performing a multivariable linear regression with the least squares method between the values of atmospheric reflectance and PM10 obtained in the field, from bands $1,2,3$, because these are part of false color, used to highlight the colors that cannot be identified in black and white. At the same time, the qualitative analysis that takes into account bands 6,9 and 11, equation 1 shows that these bands are characterized as near infrared bands used to study white areas, where a yellow color denotes low clouds and a purple color denotes high clouds. 
- $\quad$ PM10C $=$ Particle concentrations (PM10) calculated from Landsat images

$$
P M 10 C=e 0 R a t m 1+e 1 R a t m 2+e 2 R a t m 3
$$

- $\operatorname{Ratm}_{\mathrm{i}}=$ Atmospheric reflectance of bands 1, 2 and 3, obtained from satellite images

- $e_{i}=$ algorithmic coefficients determined empirically

$$
\begin{gathered}
\qquad y=m x+b \\
\text { Algorithmic coefficient }=m\left(\text { Ratm }_{i}\right)+b
\end{gathered}
$$

The coefficients $\left(e_{i}\right)$ are calculated from multivariable linear regression analysis with the method of the minimum values (equation 2) of the atmospheric reflectance (equation 3), taken from the metadata of the image captured by Landsat 8 . To have a more accurate value, the maximum and minimum difference of the reflectance and the 0 measured by RMCAB on the dates of the image capture were taken into account [21].

\section{Results}

\section{Particulate Matter}

At the MinAmbiente, CAR, San Cristóbal, Suba, Kennedy, Sevillana and Guaymaral stations, there is evidence of similar behavioral tendencies, where for 2013, higher values than those for 2015 and 2017 were recorded, with 2017 registering lower concentrations of PM10. The Tunal, Puente Aranda and Las Ferias stations, registered higher data in 2015 compared to 2013, while the Usaquén station maintains a constant concentration over the four-year period. The most significant difference in concentrations over the years is in Kennedy and Sevillana stations which, from 2013 to 2017, decreased by approximately $75 \%$ (figure 2). 
Figure 2. PM10 concentration annual average per station between 2013-2017

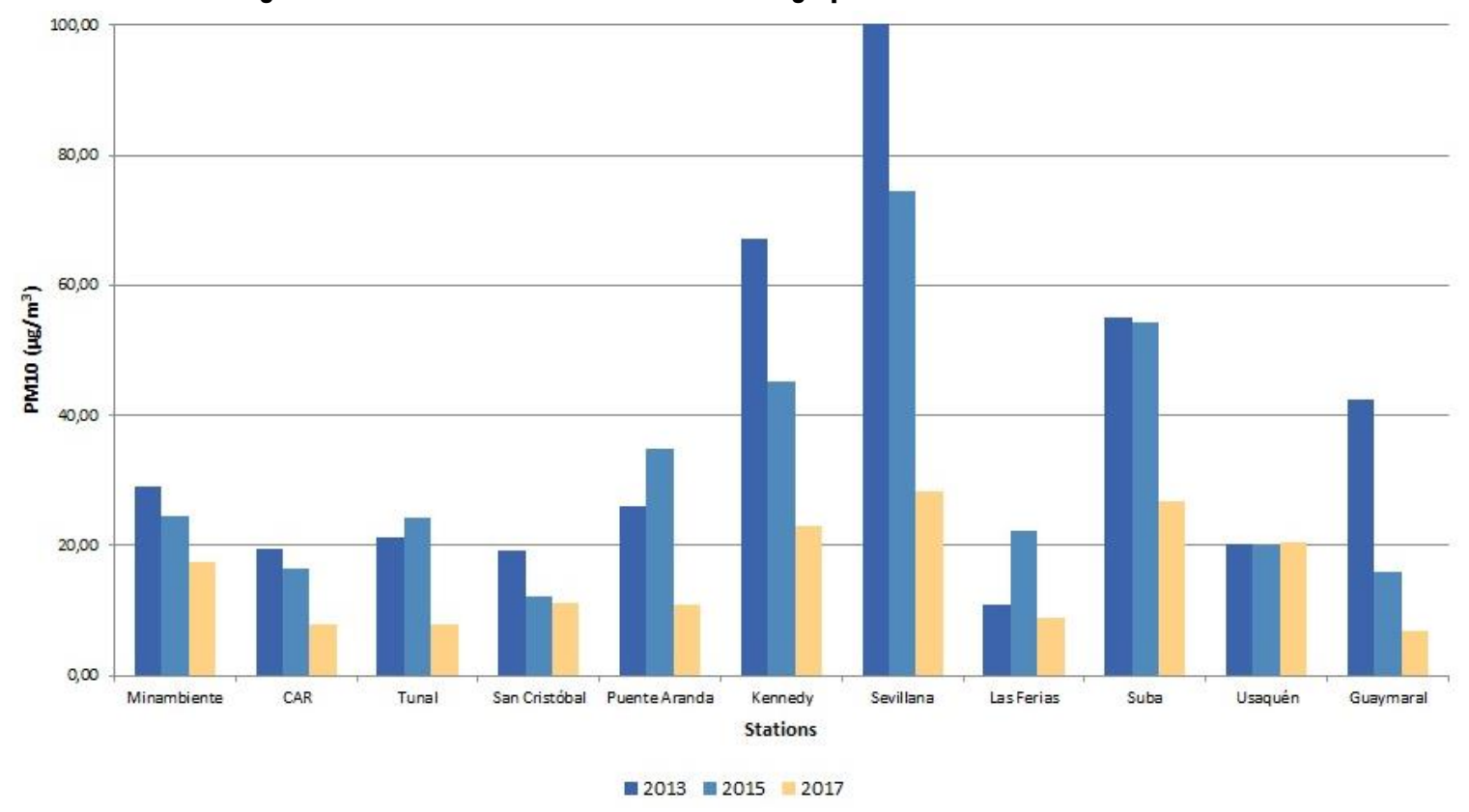

Source: own elaboration

It can be observed that in general terms, similar to the results obtained by IDEAM [18] and by Nestor Y. Rojas [11], there is a tendency for a progressive reduction in concentration levels since the beginning of operations of the monitoring network. This result may be due to the policies such as "Plan Decenal de Descontaminación del Aire para Bogotá" [24], which allows activities to be carried out from 2010 to 2020 in a coordinated manner with the necessary cooperation to achieve a better air quality. 
Wind Speed (WS) and Wind Direction (WD)

Table 3. Wind direction and wind speed during years 2013-2017 in Bogotá, per station

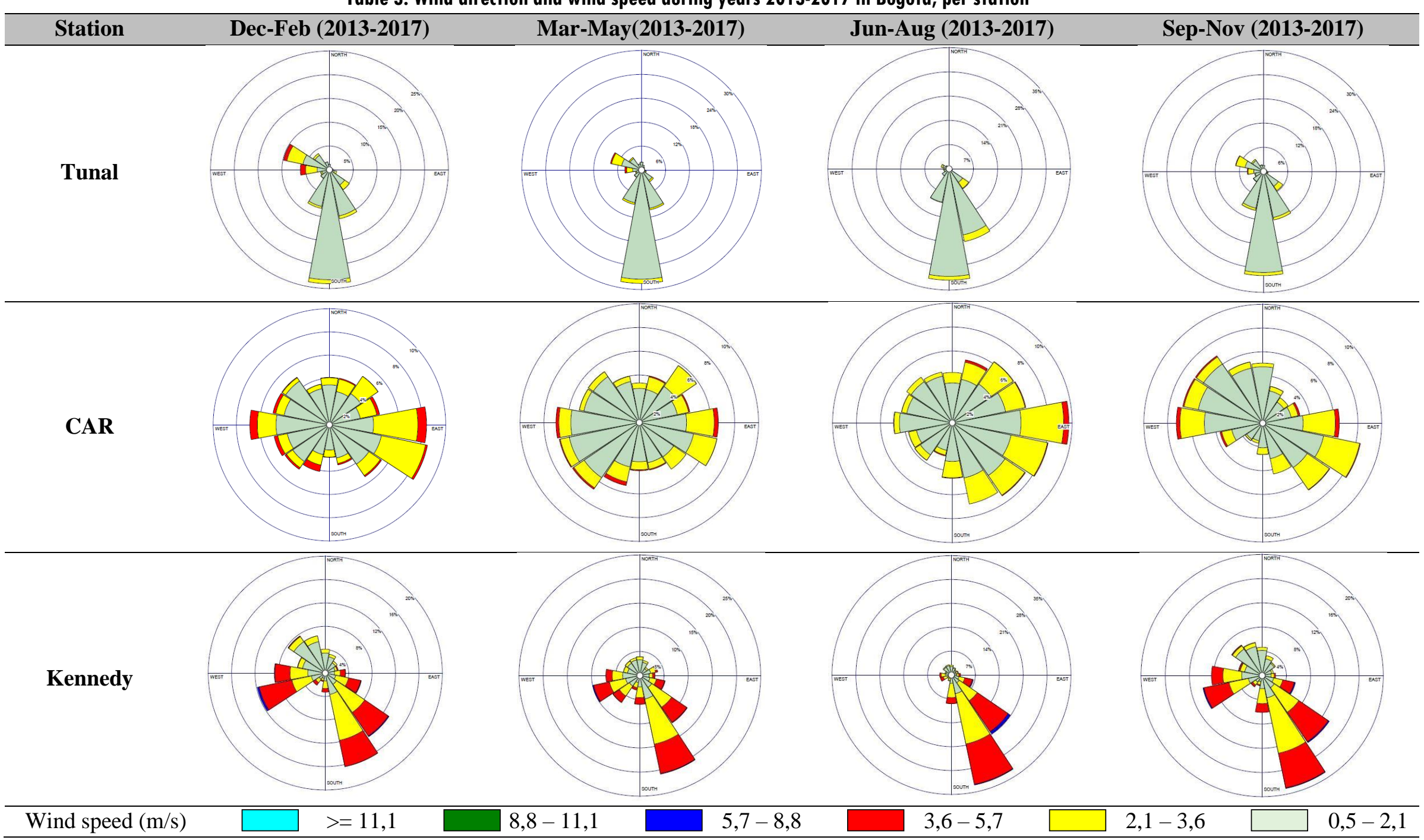




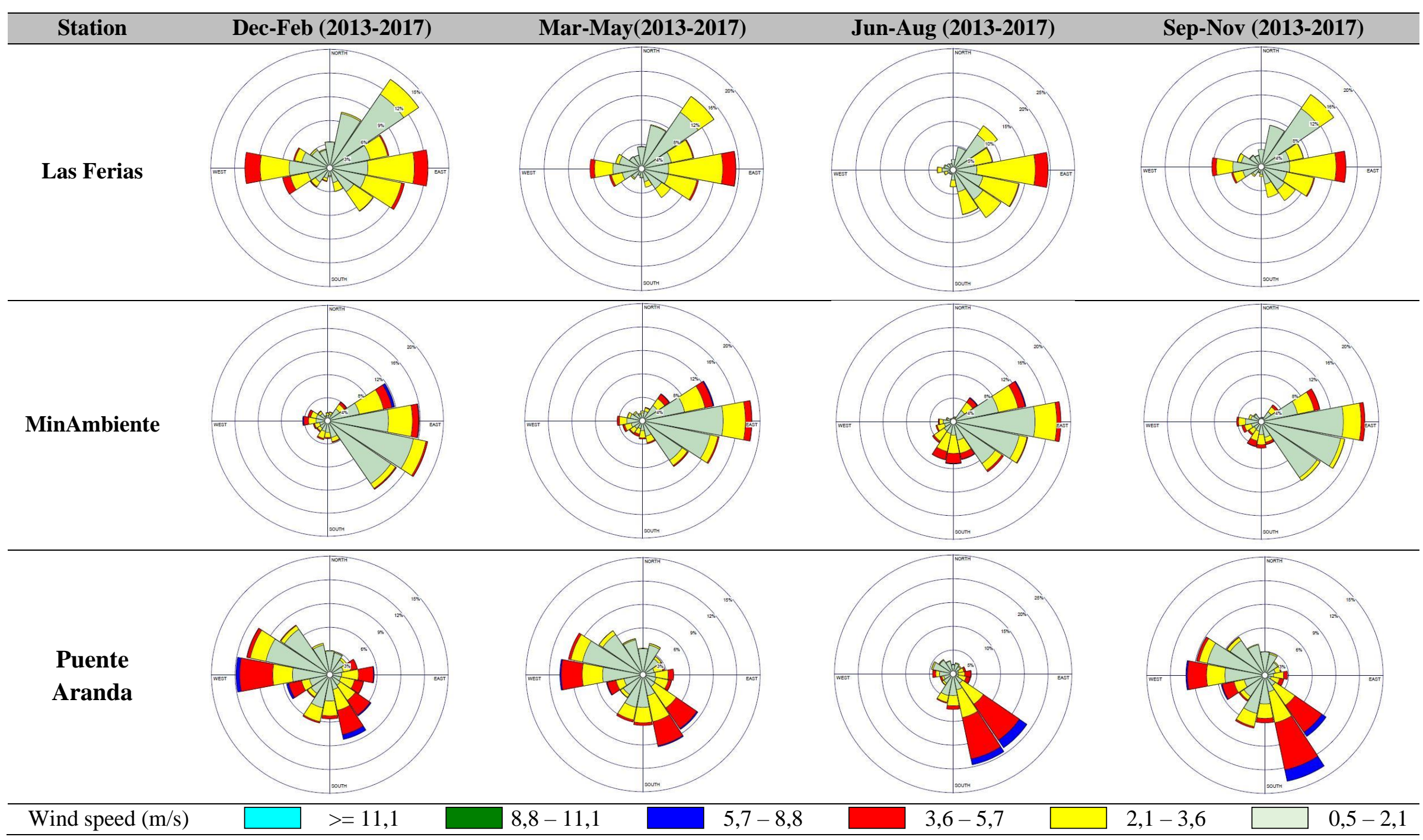




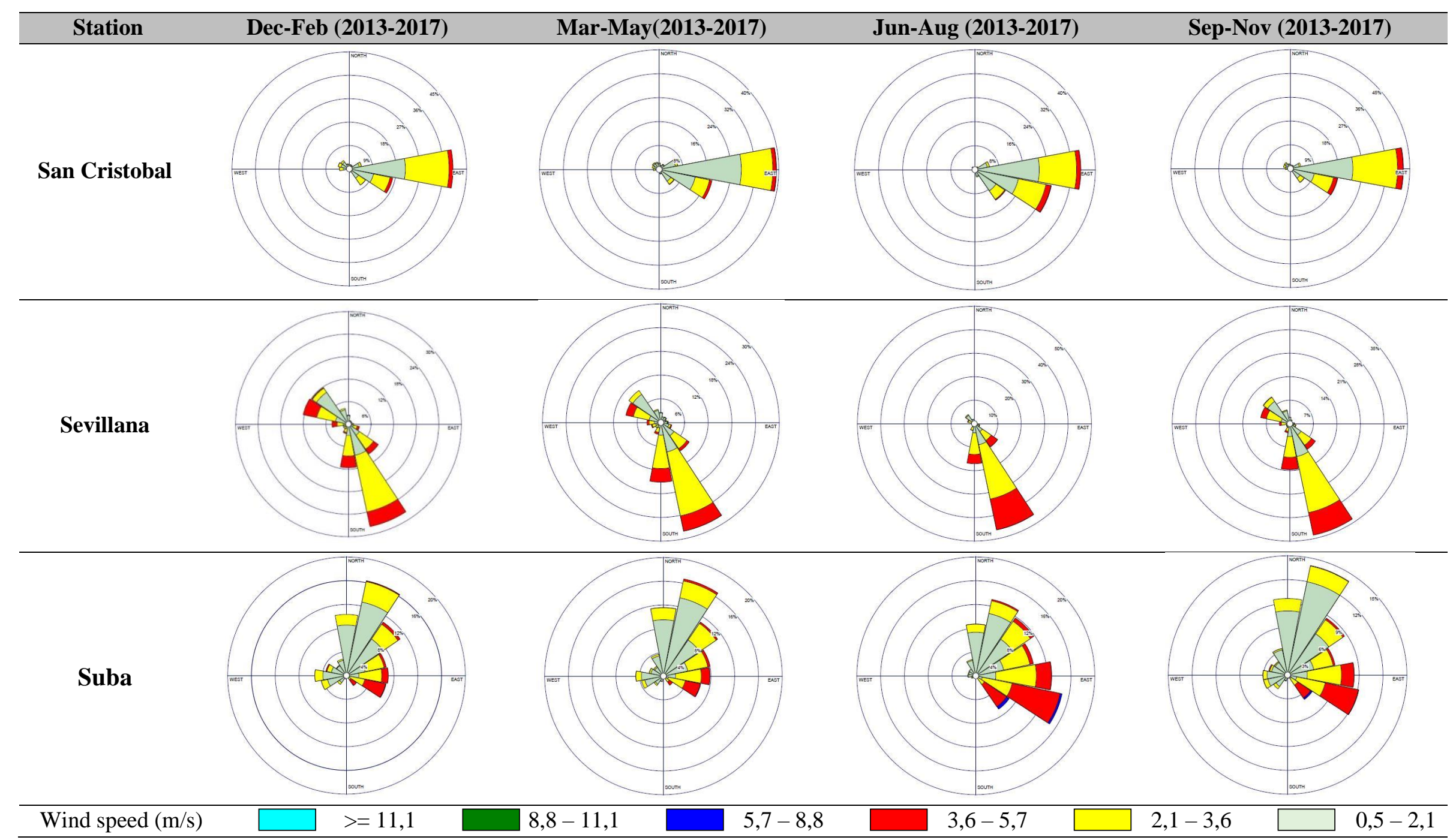




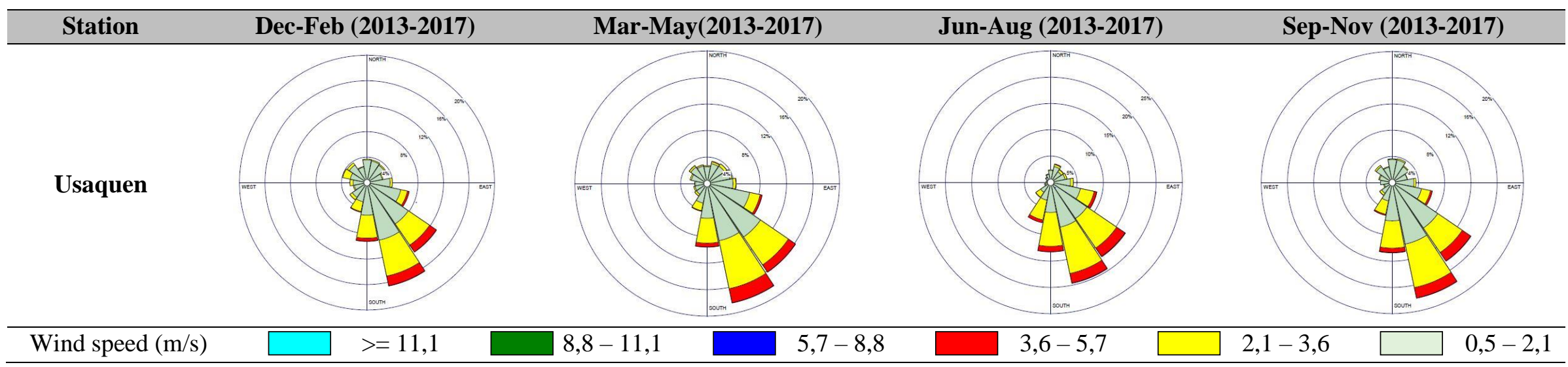

\section{Source: own elaboration}

Guaymaral belongs to the RMCAB, although the percentage of the data captured by the station was below $50 \%$. This is the reason why it was discarded for the study of this meteorological variable. According to the previous wind roses (table 3), the stations with the lowest wind speed are Tunal and San Cristóbal, and the highest is at the Puente Aranda station, reaching $8.8 \mathrm{~m} / \mathrm{s}$. It also shows that there is a wind behavior pattern that moves from east to west, except Tunal, which shows a clear direction from south to north, having a direct relation to the places that record the highest PM10 concentration levels, such as Kennedy and Sevillana. In this case, these trends might be due to their location near important streets, such as Autopista Sur and Avenida Boyacá, which contribute to the PM10 emissions in the city. This information is considered important in the reports made by the IDEAM, where they make a comparison between the industrial zones and the neighborhoods with the presence of this pollutant [3]. 


\section{Temperature}

In figure 3 can be observed that the Sevillana, Kennedy and CAR stations register higher temperatures each year compared to the others. At Kennedy, Puente Aranda and Tunal and San Cristóbal stations, the temperature increased in 2017 compared with 2015, but at Las Ferias, Sevillana and CAR, there is a tendency of temperature reduction during the same period, and Guaymaral had constant values since 2015.

Figure 3. Temperature annual average per station between 2013 and 2017

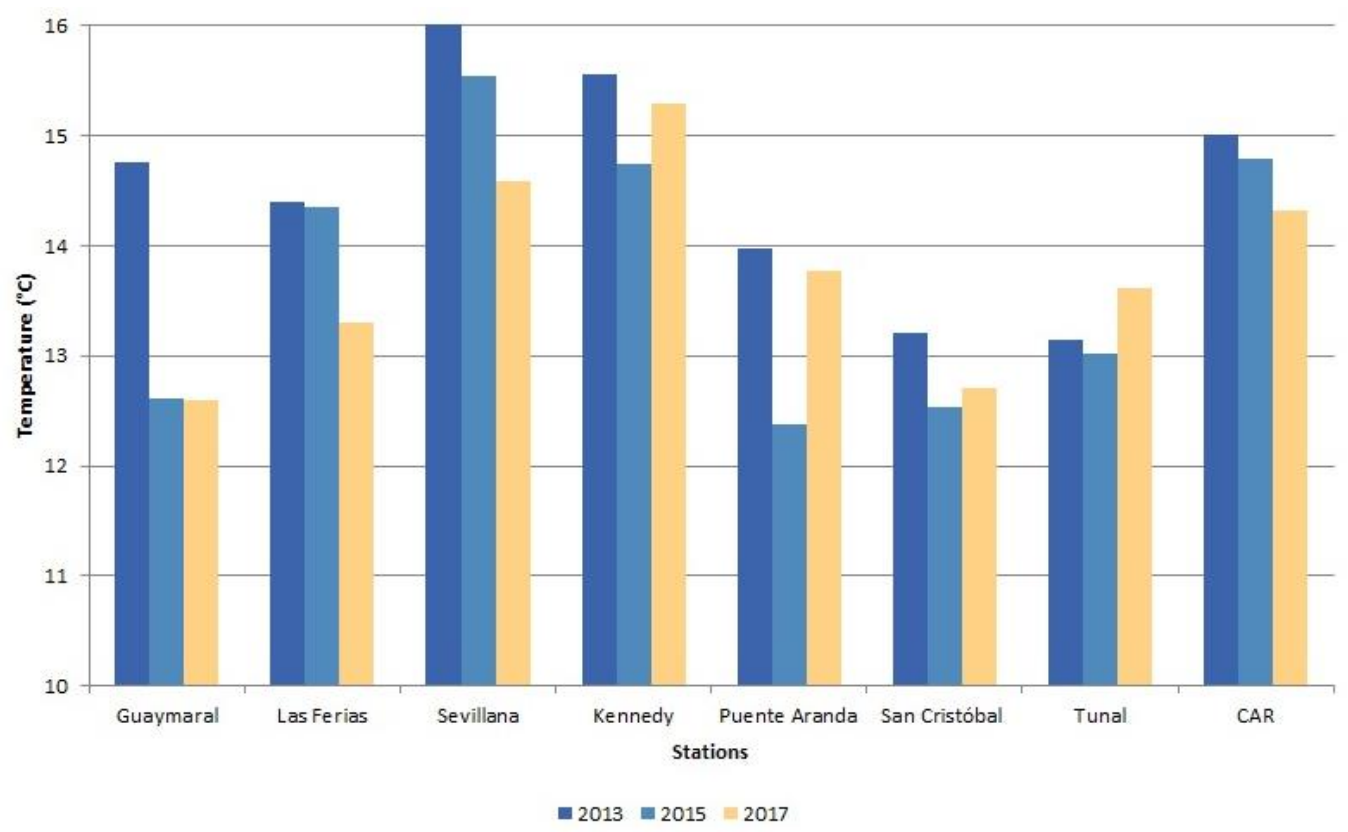

Source: own elaboration

The previous graph shows the temperature trends of eight stations in the city of Bogotá and a periodicity of daily average temperature increase for every two years. As a result, it has a relation with the values recorded and registered by the IDEAM [10]; a comparison from 1973 to 2018 , shows an increase of approximately $0.5^{\circ} \mathrm{C}-0.6^{\circ} \mathrm{C}$ during all these years. The maximum temperature estimated for the study period is $16^{\circ} \mathrm{C}$, the lowest temperature is $12.3^{\circ} \mathrm{C}$, and the standard deviation of the 8 stations is $13.7^{\circ} \mathrm{C}$.

\section{Precipitation}

In 2017, the highest precipitation data were recorded with the accumulated annual average of the stations in the city of Bogotá being a $1082 \mathrm{~mm}$ (figure 4). The year with the lowest rainfall record was 2015, with an accumulated annual average per station of $506 \mathrm{~mm}$, which 
indicates that between 2015 and 2017, the increase in precipitation was $53 \%$. The standard deviation of precipitation between 2013 and 2017 was $57 \mathrm{~mm}$ per year. The pattern of precipitation in this period is bimodal: from 2013 to 2014, there was an increase of $10 \%$; in 2015 , there was a decrease of $42 \%$ with respect to 2014; and finally, 2016 represented an increase in precipitation.

Figure 4. Precipitation annual average between 2013 and 2017

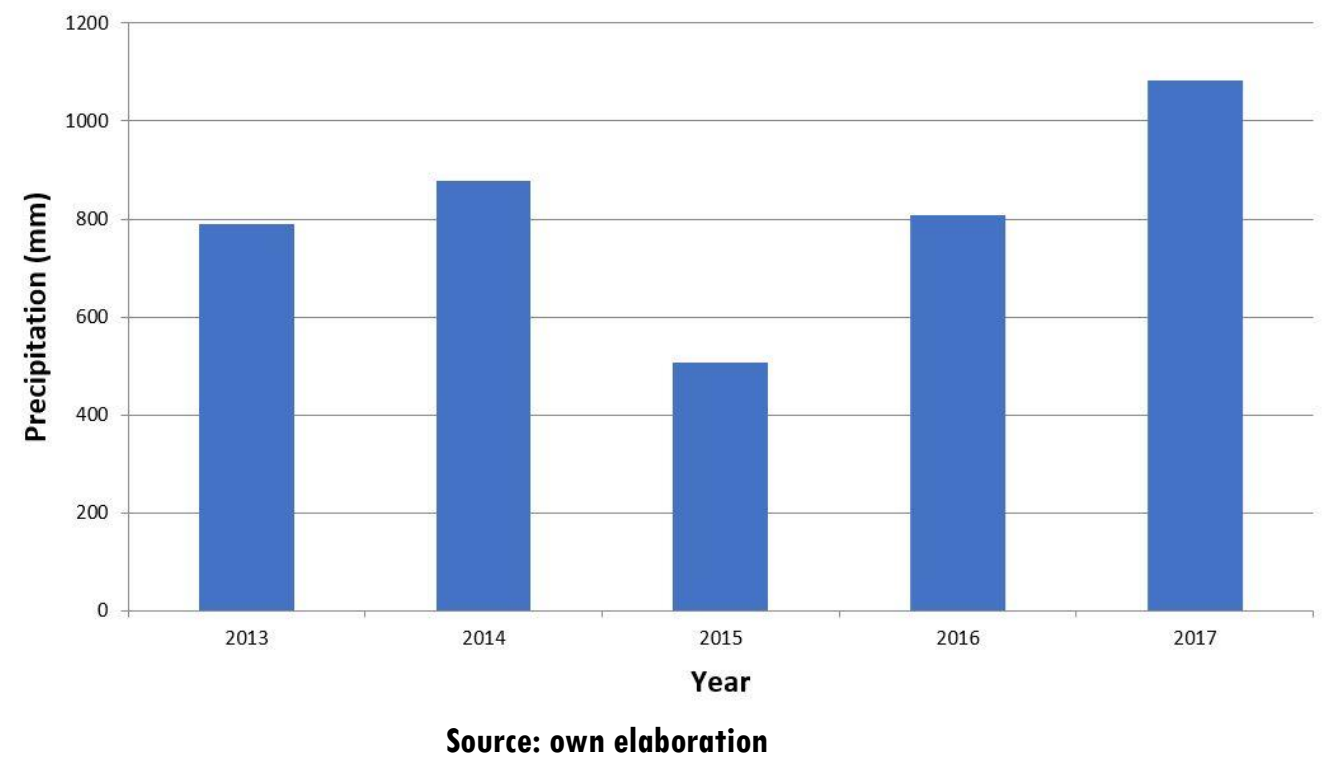

From the above, according to the report on drought and climatic variability by IDEAM, 2015 was the year that had the longest phenomenon of ENSO (El Niño-Southern Oscillation), including the rainy season of 2016. Additionally, the confirmation of the "Quality Report of the Air of Bogotá" shows that in the last quarter of 2014, an average monthly data of $132 \mathrm{~mm}$ were recorded, and in 2015, averages of $37 \mathrm{~mm}$ were reported.

\section{PM10 Calculations}

From 53 images captured by the remote sensor OLI-TIRS of Landsat 8, only 5 images are useful according to the cloud percentage (> 60\%) and the spatial correlation between the concentration isolines in the region of Bogotá through preliminary tests with panchromatic bands.

The following table shows the average daily values in each of the meteorological stations, including the dates of interest for the investigation. According to the current regulations in Colombia, the values are not above the daily permitted limit $\left(100 \mu \mathrm{g} / \mathrm{m}^{3}\right)$, different from the 
annual $\left(50 \mu \mathrm{g} / \mathrm{m}^{3}\right)$, except for Sevillana during 2013, which had $121.06 \mu \mathrm{g} / \mathrm{m}^{3}$ and 106.49 $\mu \mathrm{g} / \mathrm{m}^{3}$. The zones with the highest PM10 concentration levels are Kennedy, Sevillana and Suba, and the zones with the lowest concentration levels are CAR and Tunal (table 4).

Table 4. PM10 data $\left(\mu \mathrm{g} / \mathrm{m}^{3}\right)$-Automatic monitoring in Bogotá

\begin{tabular}{cccccc}
\hline Station & $\mathbf{2 9 / 1 0 / 2 0 1 3}$ & $\mathbf{2 7 / 0 9 / 2 0 1 3}$ & $\mathbf{3 1 / 0 7 / 2 0 1 5}$ & $\mathbf{1 7 / 0 7 / 2 0 1 6}$ & $\mathbf{0 4 / 0 7 / 2 0 1 7}$ \\
\hline Tunal & 54.37 & 21.30 & 24.21 & 24.65 & 7.75 \\
\hline CAR & 35.73 & 19.45 & 16.44 & 12.43 & 7.75 \\
\hline Kennedy & 67.15 & 67.29 & 45.23 & 39.85 & 22.95 \\
\hline Minambiente & 54.61 & 29.11 & 24.42 & 16.60 & 17.51 \\
\hline San Cristóbal & 34.73 & 19.23 & 12.05 & 12.69 & 11.04 \\
\hline Usaquén & 45.66 & 20.22 & 19.93 & 21.60 & 20.58 \\
\hline Guaymaral & 77.91 & 42.51 & 16.00 & 17.96 & 6.82 \\
\hline Las Ferias & 36.60 & 10.90 & 22.26 & 17.55 & 8.93 \\
\hline Sevillana & 121.03 & 106.49 & 74.41 & 39.71 & 28.29 \\
\hline Puente Aranda & 68.35 & 26.05 & 34.80 & 21.92 & 11.00 \\
\hline Suba & 76.66 & 55.01 & 54.27 & 35.50 & 26.83 \\
\hline
\end{tabular}

Source: own elaboration

According to air quality reports, the highest concentrations and excesses over national regulations are in the Carvajal, Kennedy and Puente Aranda stations due to the influence of its surroundings characterized by the presence of a high activity from mobile sources as well as industrial sources. On the other hand, the stations that register the lowest values are Guaymaral, Usaquén, MinAmbiente and San Cristóbal. These four measurement sites generally report less dispersion in their respective data. Of the total data recorded in the previous representative sample, composed of the five days recorded, $3.6 \%$ exceeded the value of the daily norm, a percentage equivalent to 2 values in Sevillana.

The satellite image of the same date allows us to determine the relationship of the formation and dispersion of clouds in Bogotá. The meteorological variables included are the date of the image, the accumulated values of PM10 $\left(\mu \mathrm{g} / \mathrm{m}^{3}\right)$ from every meteorological station, the data obtained from the metadata, and the result as follows (table 5): 
Table 5. PM10 Calculation equation per image

\begin{tabular}{cccc}
\hline Image & $\begin{array}{c}\text { PM10 } \\
\text { monitored } \\
\left(\boldsymbol{\mu g} / \mathbf{m}^{\mathbf{3}}\right)\end{array}$ & $\begin{array}{c}\text { PM10 } \\
\text { Measurement }\end{array}$ & $\begin{array}{c}\text { PM 10 }\left(\boldsymbol{\mu g} / \mathbf{m}^{3}\right) \\
\text { Results }\end{array}$ \\
\hline $27 / 09 / 2013$ & 417.554167 & $=0.29406 \mathrm{~B} 1+0.27006 \mathrm{~B} 2+0.35043 \mathrm{~B} 3$ & 312.864971 \\
\hline $29 / 10 / 2013$ & 672.804167 & $=0.19961 \mathrm{~B} 1+0.19417 \mathrm{~B} 2+1.21236 \mathrm{~B} 3$ & 211.653025 \\
\hline $31 / 07 / 2015$ & 344.033333 & $=0.35714 \mathrm{~B} 1+0.20964 \mathrm{~B} 2+0.70351 \mathrm{~B} 3$ & 418.118445 \\
\hline $17 / 07 / 2016$ & 260.441667 & $=0.48941 \mathrm{~B} 1+0.53106 \mathrm{~B} 2+0.39166 \mathrm{~B} 3$ & 473.529123 \\
\hline $04 / 07 / 2017$ & 169.440833 & $=0.51575 \mathrm{~B} 1+0.49421 \mathrm{~B} 2+1.044365 \mathrm{~B} 3$ & 486.054618 \\
\hline & \multicolumn{2}{c}{ Source: own elaboration }
\end{tabular}

The next graph (figure 5) shows, as in calculations, a decreasing trend in the generation of particulate matter as seen in the images, with a negative slope, and a relation between variables of R2: 0.9426; thus, a linear regression is obtained with a coefficient $\mathrm{R}$ equal to $94.26 \%$. This indicates that the results of PM10 concentration levels are very similar, once the monitored and the calculated values are compared.

Figure 5. Processing of satellite images using digital image processing

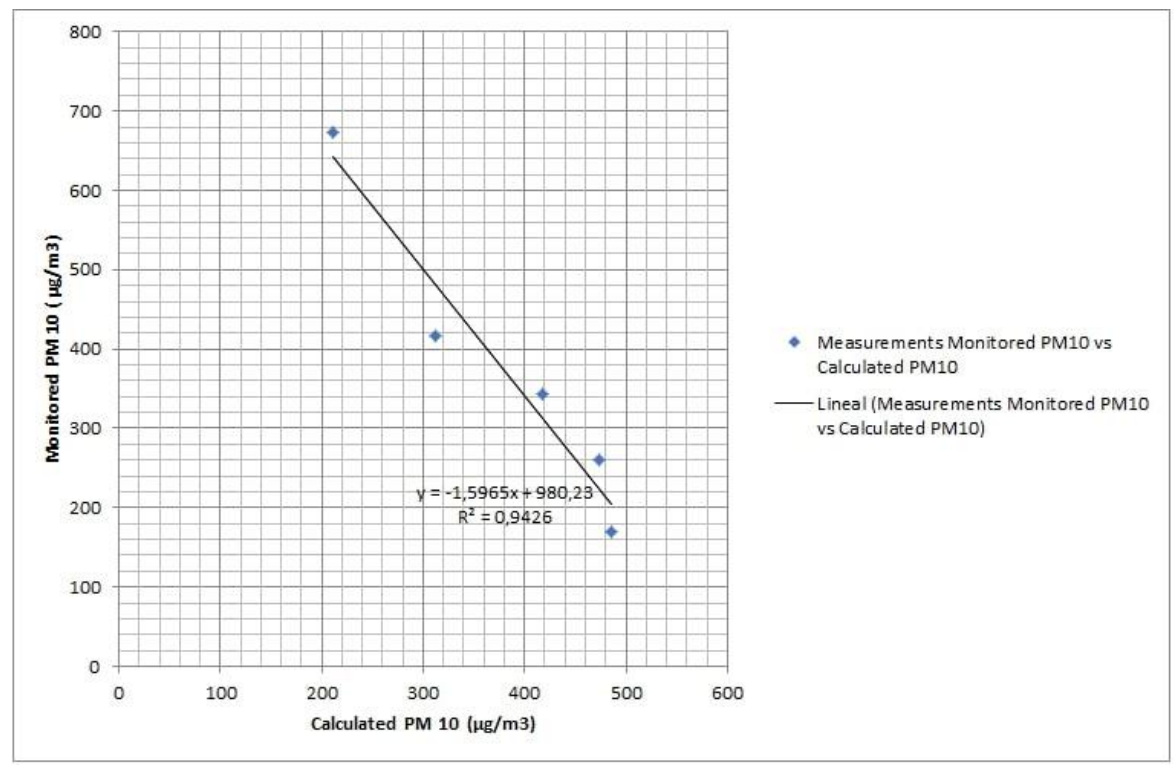

Source: own elaboration

Considering the relationship between the calculated PM10 and the monitored PM10, the satellite image of the same date allows us to determine the relationship of cloud formation and dispersion in Bogotá. This also includes the meteorological variables in the following way, where some behavior patterns were confirmed by the Geographic Information System ArcGis due to the information analysis that was realized by combining every variable, allowing us to produce the following maps (figure 6): 
Figure 6. PM10 map in Bogotá (27/09/2013, 31/07/2015, 04/07/2017)
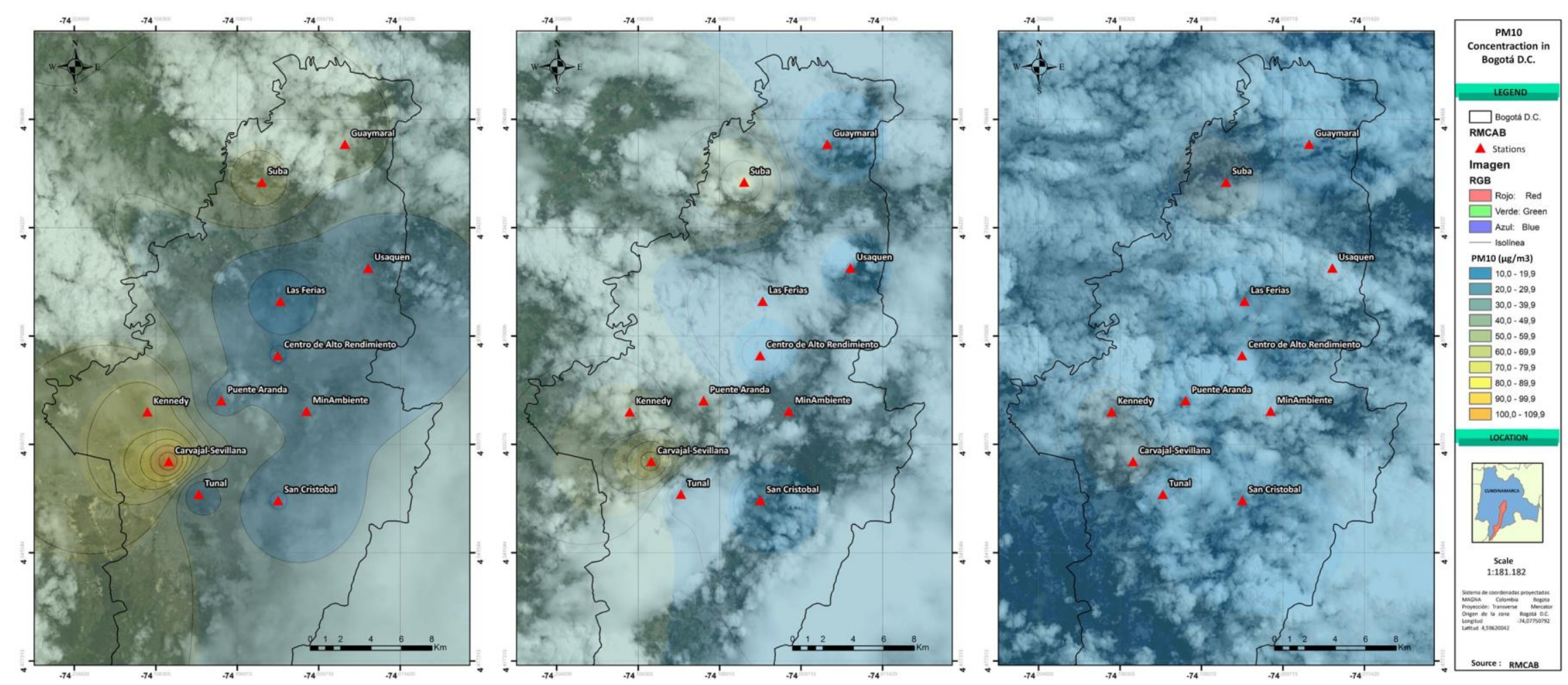

\section{Source: own elaboration}

From the previous images, it is evident that the highest concentration of PM10 occurs in the zones where the color tends to red, which corresponds to Kennedy, Puente Aranda and Sevillana. This is similar to the values registered by the IDEAM [18], where these are the stations with the highest PM10 concentration levels. The cloud formation compared to the concentration of this pollutant shows cumulonimbus and low clouds in the southeast of the city where concentrations above $80 \mu \mathrm{g} / \mathrm{m}^{3}$ are present. In areas with low concentrations of PM10, there are high and medium clouds. The stations of CAR, Tunal, Usaquén, Minambiente and San Cristóbal 
record PM concentrations lower than $20 \mu \mathrm{g} / \mathrm{m}^{3}$ day. In contrast, the stations of Suba, Kennedy and Sevillana reiterate in the three images above $70 \mu \mathrm{g} / \mathrm{m}^{3}$ day. The other stations, such as Puente Aranda and Guaymaral, registered a negative slope of concentration of PM10 in the study period. The western zone of the city has a higher concentration of particulate matter, PM10, than the eastern zone, as well as greater formation of low cumulus clouds. However, in the west of the city, the formation of medium strata clouds predominates.

Figure 7. Temperature map in Bogotá (27/09/2013, 31/07/2015, 04/07/2017)
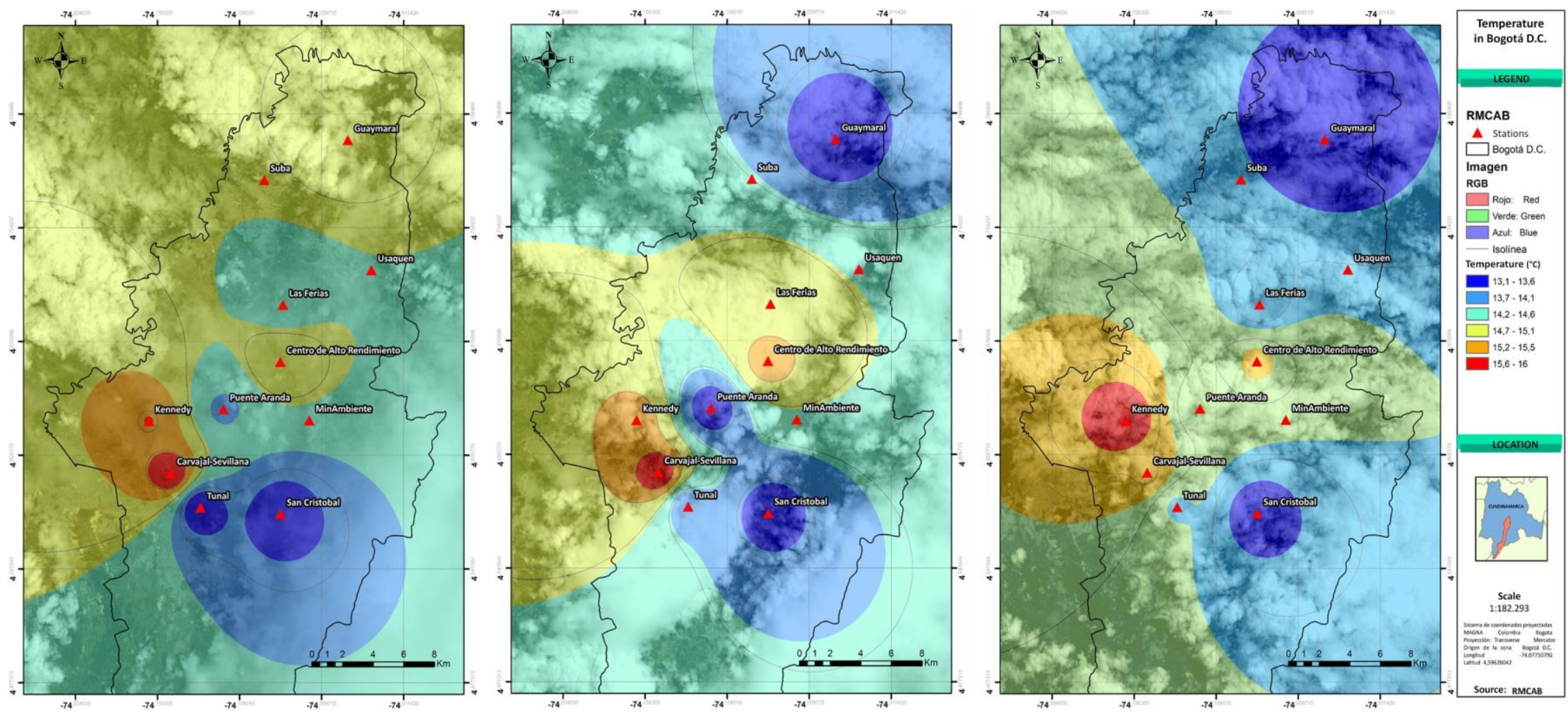

Source: own elaboration 
These images (figure 7) show that the places with the highest temperatures present low clouds and are part of the group of stations with the highest PM10 concentration values (Kennedy, Sevillana). Comparing this to different reports of health and air quality [25] makes evident a directly proportional relation between these two factors.

The station of San Cristóbal and Tunal in the progression of the three images recorded temperatures lower than $14{ }^{\circ} \mathrm{C}$. The image recorded on $08 / 27 / 2013$ (image on the left) has a coverage of $60 \%$ of temperatures above $15{ }^{\circ} \mathrm{C}$. In the western zone of the city, the second image of $31 / 07 / 2015$ has the highest coverage of low temperatures under $14.6{ }^{\circ} \mathrm{C}$, and the coverage is $72 \%$, with a predominance in the eastern zone. The image registered on 04/07/2017 (image on the right) presents in the Guaymaral station the largest representative area of approximate temperature of $13{ }^{\circ} \mathrm{C}$. However, the west of the city has $53 \%$ coverage of temperatures above $15{ }^{\circ} \mathrm{C}$, and the east has $47 \%$ coverage with temperatures below $15^{\circ} \mathrm{C}$. 
Figure 8. Wind speed map in Bogotá (27/09/2013, 31/07/2015, 04/07/2017)
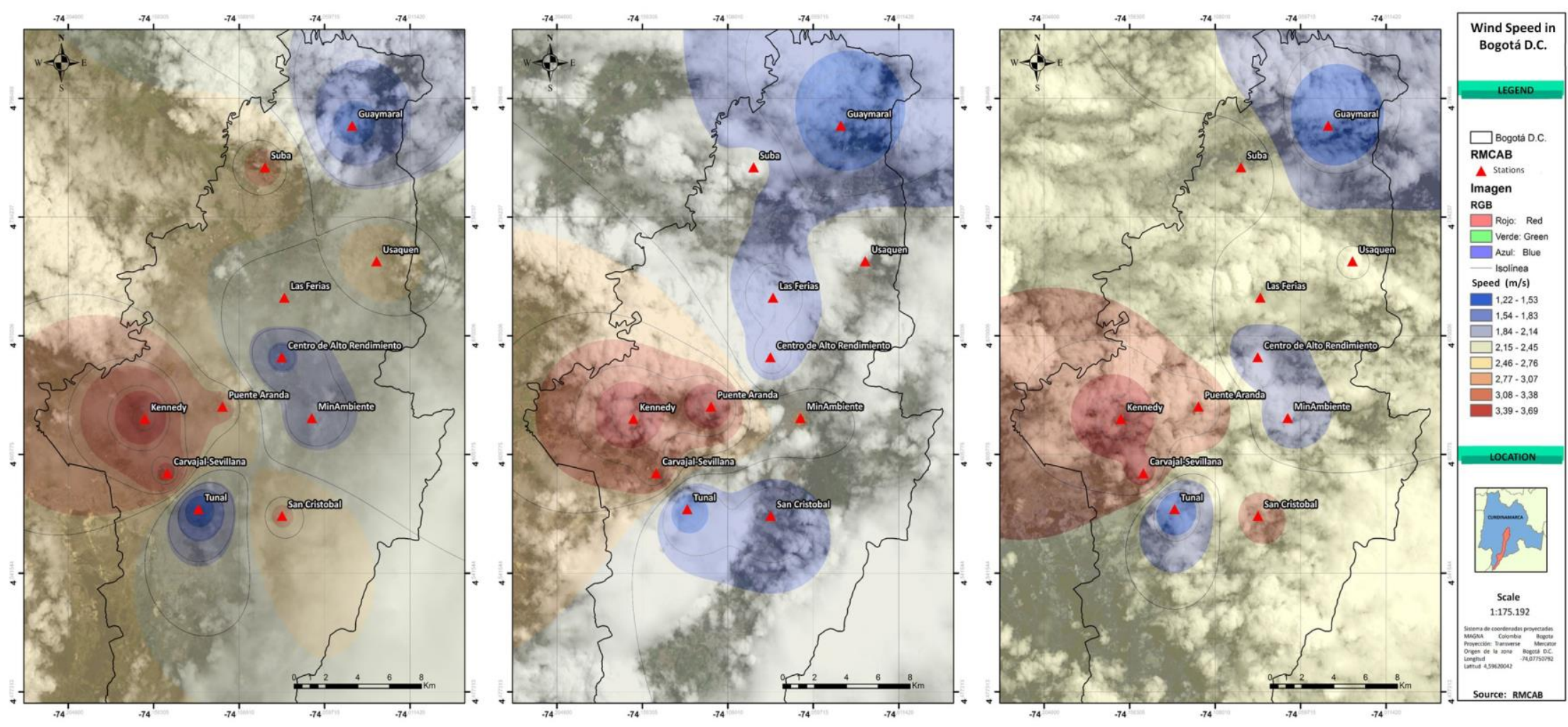

Source: own elaboration

The Kennedy, Sevillana and Puente Aranda stations record higher speeds of $2.8 \mathrm{~m} / \mathrm{s}$ daily, located in the southwest of the city. Additionally, Tunal, CAR and Guaymaral maintain a constant pattern of behavior of low speeds below $2.5 \mathrm{~m} / \mathrm{s}$. These monitoring points are located in the southwest, center and north-east of the city, indicating that there is a trend of low-speed winds that crosses the south of the city to the north. Furthermore, stations that record high speeds are part of the areas of the city where buildings are shorter. On the one hand, higher speed areas present few clouds, which indicates the displacement of high clouds. Low clouds are evident in areas of higher wind speed; in the same way, the areas where there is more speed coincide with areas of higher concentration, that is, 
Kennedy and Sevillana. On the other hand, in Suba where lower speed is recorded, average clouds predominate and are characteristic of good weather (figure 8).

Figure 9. Wind direction map in Bogotá (27/09/2013, 31/07/2015, 04/07/2017)
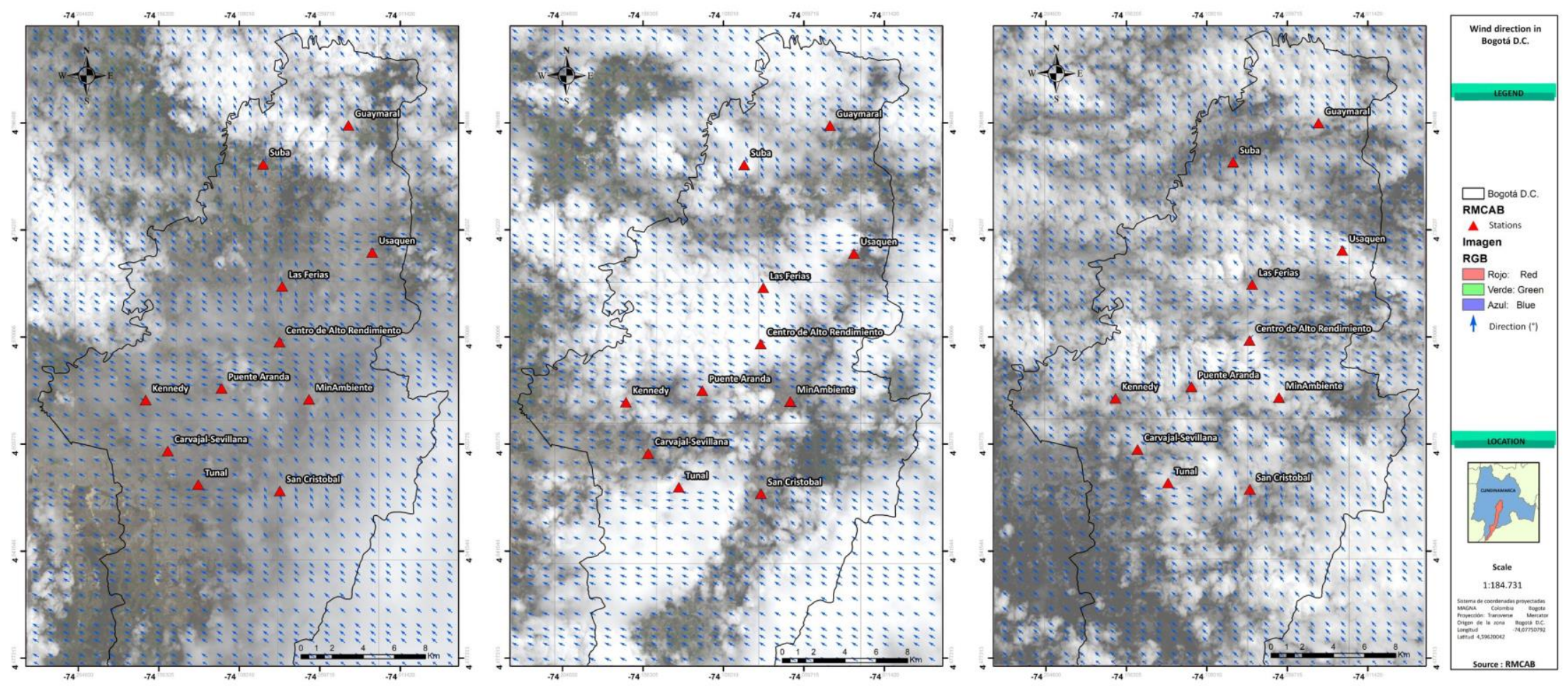

\section{Source: own elaboration}

The previous wind direction maps (figure 9) agree with the dispersion of clouds in Bogotá; in the same way, the wind direction predominates in the southwest direction, and it is considered that the dispersion of PM10 has a tendency towards Kennedy, Sevillana and Puente Aranda. The behavior of the wind direction for the region of Bogota registered in the image of 27/09/2013 is from the south-east towards the north-west. Over the monitoring area of Kennedy and Suba, there is dispersion of clouds towards the west and 
north, respectively, which, according to the direction of the wind, corresponds to the coverage of the cleared area in the center of the city. In the image captured on 31/07/2015, the direction of the wind coming from the west and going westward with a greater horizontal tendency compared to the image of 2013. Finally, in the image of 04/07/2017, the wind presents a behavior of deviation in the Tunal and Sevillana stations, and the wind that comes from the southeast does not have a parallel behavior towards the north-east, from heading towards the southwest. The clouds that are formed in the three images correspond to low cumulus in the west and high strata in the east, which, according to the direction of the wind, is the area where the winds come from and favors the formation of high clouds and the area where lead wind favors the formation of low clouds.

\section{Figure 10. Combination of spectral bands 6, 9 and 11}
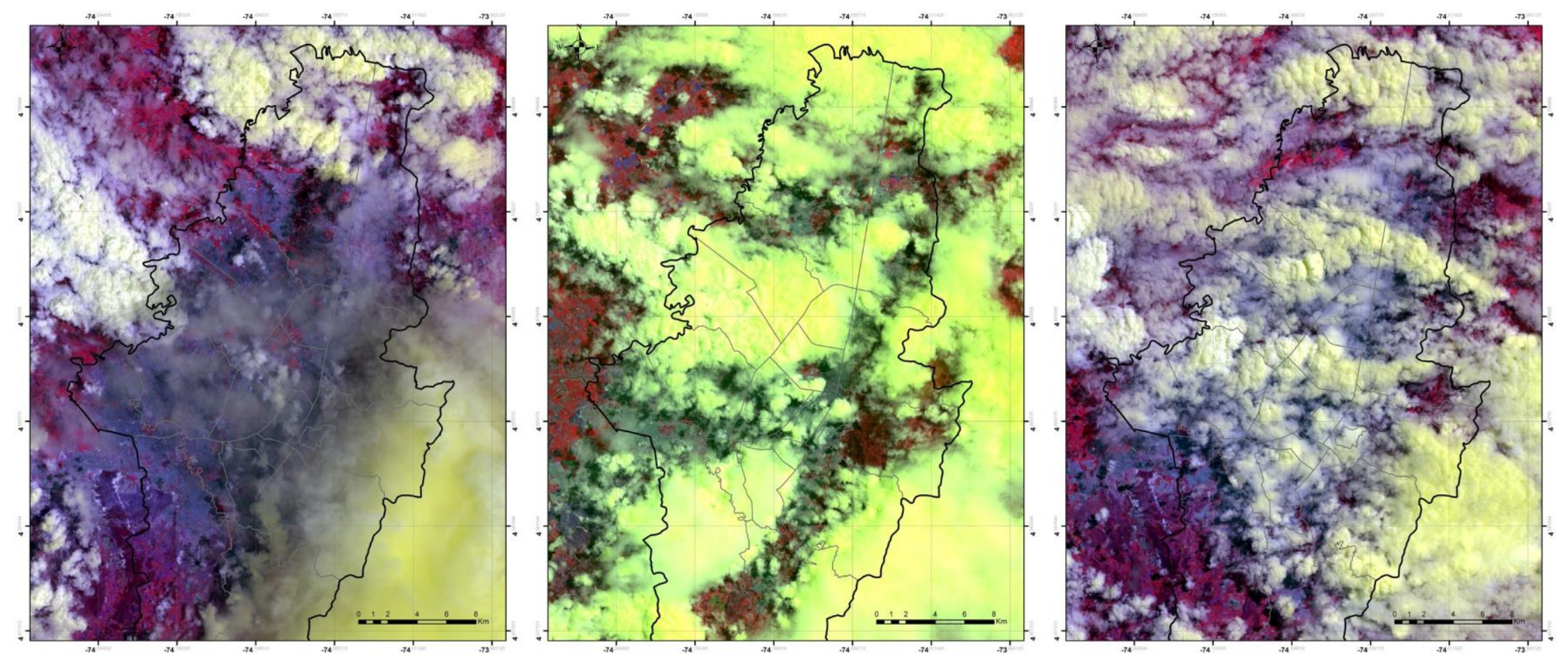

Source: own elaboration

INGENIERÍA Y UNIVERSIDAD: ENGINEERING FOR DEVELOPMENT | COLOMBIA | V. 23 | N0. 2 | 2019 | ISSN: 0123-2126 /2011-2769 | Pág. 23 
A combination of the spectral bands (figure 10) was made taking into account bands 6, 9 and 11 . These are characterized by being near infrared bands used to study white areas that, for the case of clouds, denote yellow for low clouds and purple for high clouds. From the previous images, it is seen that cloud edges present a green tonality associated with the contrast of the shade and hour of the image. The upper parts of the lighter colors indicate that the accumulation of PM10 occurs in low clouds.

\section{Conclusions}

According to the results, places with low cloud formation can present PM10 at high concentration levels, with high temperatures and high values of wind speed directed towards the west. This result can also be due to the influence of high buildings that are located in the center of the city, which especially affect stations such as Kennedy, Sevillana and Puente Aranda.

Remote sensing methods of PM support the installation of monitors on land. The complexity of conducting remote sensing in the clouds is given by the height from which it is monitored on land, which in the case of Bogotá, is $12 \mathrm{~m}$ on average. However, it was determined that in areas where there is a greater PM10 concentration, there is formation of low clouds.

Displacement vectors can be obtained from the speed and direction of the clouds and similarly for the PM10 in a 1/3 proportion, where the clouds are mostly displaced.

Both dust and smoke interact with shorter wavelengths reflecting light back to the sensor, so the reflectance indices are high.

In conclusion, this type of research can be useful where there are insufficient resources to acquire high technology equipment, and this approach is an easy and low-cost method to study air quality. This method allows the possibility of creating strategies to avoid or reduce respiratory diseases and develop strict and strong regulations.

\section{References}

[1] World Health Organization (WHO), "Calidad del aire y salud," April 2016. [Online]. Available: https://www.who.int/es/news-room/fact-sheets/detail/ambient-(outdoor)-air-quality-and-health. Accessed: May 24, 2017.

[2] Ministerio de Ambiente y Desarrollo Sostenible (MADS), "Diagnóstico Nacional de Salud Ambiental," Colombia, 2012.

[3] Instituto de Hidrología, Meteorología y Estudios Ambientales (IDEAM), "Segundo boletín sobre contaminación atmosférica,” Subdirección de Estudios Ambientales IDEAM, Colombia, 2016. 
[4] J. Bocarejo et al., "Caracterización de la contaminación atmosférica en Colombia," University College London-Universidad de los Andes, Colombia, 2013.

[5] M. Khallaf, "The impact of air pollution on heatlh, economy, environment and agricultural sources," In. Tech., Rijeka, Croatia, 2011.

[6] D. Rosenfield and W. Woodley, "Pollution and clouds," Physics World, no. 2, pp. 33-37, 2001. doi: $10.1088 / 2058-7058 / 14 / 2 / 30$

[7] V. Kayetha and R. Collins, "Optically thin midlevel ice clouds derived from Cloud Aerosol Lidar and Infrared Pathfinder Satellite Observations," J. Appl. Remote Sens., vol. 10, no. 4, Oct.-Dec. 2016. doi: $10.1117 / 1 . J R S .10 .046007$

[8] O. Barrios Correa, "Contaminación del ambiente por material particulado generado en las obras civiles," thesis, Dep. Ing. Civ., Univ. Sucre, Sincelejo, Colombia, 2017.

[9] H. Weitzenfeld, "Problemas de contaminación del aire en America Latina y El Caribe," Mexico, 2012. Available: http://www.bvsde.paho.org/bvsacd/eco/023999.pdf

[10] Instituto de Hidrología, Meteorología y Estudios Ambientales (IDEAM), "Región Andina Temperatura," July 2018. [Online]. Available: http://www.ideam.gov.co/web/tiempo-yclima/region-andina-temperatura.

[11] N. Rojas, Aire y problemas ambientales de Bogotá. Bogotá: Universidad Nacional de Colombia, 2012.

[12] E. Behrentz, J. Cancino, and M. Gaitán, "Análisis del estado de la calidad del aire en Bogotá," Rev. Ing., no. 26, pp. 81-92, 2007. doi:10.16924/riua.v0i26.299.

[13] L. Chaparro, M. Cuervo, J. Gómez, and M. Toro, Emisiones al ambiente en Colombia. Bogotá: IDEAM, 2001. Available: http://documentacion.ideam.gov.co/openbiblio/bvirtual/000001/cap13.pdf G. Torres, “¿Cuál es la sorprendente 'ciudad más contaminada' de América Latina?,” $B B C$, May 13, $2016 . \quad$ [Online]. Available: https://www.bbc.com/mundo/noticias/2016/05/160513_ciencia_ciudad_mas_contaminada_ameri ca_latina_gtg. Accessed: Jan. 22, 2018.

[15] Instituto de Hidrología, Meteorología y Estudios Ambientales (IDEAM), "Informe del estado de la calidad del aire en colombia (2007-2010)," Bogotá, 2012. Available: http://documentacion.ideam.gov.co/openbiblio/bvirtual/022433/CALIDADDELAIREWEB.pdf

[16] Ministerio de Ambiente y Desarrollo Sostenible (MAVDT). (2016, Apr. 4). Resolución 601. [Online]. Available: http://www.minambiente.gov.co/images/normativa/app/resoluciones/59Resolución\%20601\%20de\%202006\%20-\%20calidad\%20de1\%20aire.pdf

[17] Ministerio de Ambiente y Desarrollo Sostenible (MAVDT). (2010, March 24). Resolución 610. [Online]. Available: http://www.minambiente.gov.co/images/normativa/app/resoluciones/bfResolución\%20610\%20de\%202010\%20-\%20Calidad\%20del\%20Aire.pdf

[18] Instituto de Hidrología, Meteorología y Estudios Ambientales (IDEAM), "Informe del estado de la calidad del aire en colombia (2011-2015),” Bogotá, 2016. Available: http://documentacion.ideam.gov.co/openbiblio/bvirtual/023637/Informe_del_Estado_de_la_Calid ad_del_Aire_en_Colombia_2011-2015_vfinal.pdf

[19] S. Appadurai and J. Colins, "Satellite based estimation of PM10 from aot of Landsat 7ET+OVER Chennai City," Int. J. Adv. Eng. Res., vol. 11, no. 4, pp. 62-68, 2016. Available: https://www.ijaer.com/images/short_pdf/1501822032_Sam_Appadurai_C9_9.pdf

[20] A. Shadden, A. Kidwai, N. Ain, and A. Zeeshan, "Estimating air particulate matter 10 using Landsat multi-temporal data and analyzing its annual temporal pattern over gaza strip, Palestine," J. Asian Sci. Res., vol. 7, no. 2, pp. 22-37, 2017. doi: 10.18488/journal.2/2017.7.2/2.2.22.37

[21] C. Alvarez and O. Padilla, "Estimación de contaminación del aire por PM10 en Quito, determinado por índices ambientales obtenidos con imágenes satelitales Landsat EM+," Universidad de las Fuerzas Armadas ESPE, pp. 1-11, 2014. Available: https://repositorio.espe.edu.ec/bitstream/21000/8753/1/AC-SGA-ESPE-047962.pdf

[22] L. Santana and L. E. Capote P., "Estimación de un índice de calidad ambiental urbano, a partir de imágenes de satélite," Rev. Geog. Norte Grande, no. 45, pp. 77-95, 2010. doi: 10.4067/S071834022010000100006

[23] Secretaría Distrital de Ambiente (SDA), "Red de Monitoreo de Calidad del Aire de BogotáRMCAB," 2010. [Online]. Available: http://ambientebogota.gov.co/web/sda/red-de-calidad-delaire. Accessed: May 21, 2017. 
[24] Secretaría Distrital de Ambiente (SDA), "Plan Decenal de Desontaminación del Aire para Bogotá," Bogotá, $2010 . \quad$ Available: http://ambientebogota.gov.co/en/c/document_library/get_file?uuid=b5f3e23f-9c5f-40ef-912a51a5822da320\&groupId=55886

[25] Hospital Suba, "Boletín Informativo Calidad del Aire y Salud," Aug. 2009. [Online]. Available: http://www.saludcapital.gov.co/sitios/VigilanciaSaludPublica/Informacin\%20general\%20para\%2 0descargas/Boletines\%20epidemiologicos/Boletines\%20calidad\%20aire\%20y\%20salud/2009/Su ba/8\%20BOLETIN\%20AGOSTO\%20CALIDAD\%20DEL\%20AIRE\%20Y\%20SALUD.pdf

[26] F. Lutgens and E. Tarbuck, The Atmosphere, an Introduction to Meteorology, 13 ed. New Jersey: Pearson, 2016.

[27] Y. Leon, Introducción a las imágenes satelitales, INTEC, República Dominicana, 2002. Available: https://nanopdf.com/download/introduccion-a-las-imagenes-satelitales_pdf

[28] Ministerio de Ambiente y Desarrollo Sostenible (MAVDT), "Política de Prevención y Control de la Contaminación del Aire.” Bogotá: Author, 2010. Available: http://www.minambiente.gov.co/index.php/asuntos-ambientales-sectorial-y-urbana/gestion-delaire/politica-de-prevencion-y-control-de-la-contaminacion-del-aire-ppcca\#tdocumentosrelacionados

[29] Red de Monitoreo de Calidad del Aire de Bogotá (RMCAB), "Sitio web de información ambiental." [Online]. Available: http://201.245.192.252:81/

[30] Gretl, "Gnu regression, econometrics and time-series library." [Online]. Available: http://gretl.sourceforge.net/

[31] Lakes Environmental, "WRPLOT View ${ }^{\text {TM}}$-Freeware." [Online]. Available: https://www.weblakes.com/products/wrplot/index.html

[32] Earth Observing System (EOS). EOS Land Viewer. [Online]. Available: https://eos.com/landviewer/

[33] M. Goodchild, "Geographic information systems and science: Today and tomorrow," Proc. Earth Planetary Sci., vol. 1 , no. $1, \quad$ pp. 1037-1043, 2009. Available: https://doi.org/10.1016/j.proeps.2009.09.160 